\title{
Effects of the audit committee and the fiscal council on earnings
} quality in Brazil*

\author{
Vitor Gomes Baioco \\ Universidade Federal do Espírito Santo, Centro de Ciências Jurídicas e Econômicas, Departamento de Ciências Contábeis, Vitória, ES, Brazil
}

José Elias Feres de Almeida

Universidade Federal do Espírito Santo, Centro de Ciências Jurídicas e Econômicas, Departamento de Ciẹncias Contábeis, Vitória, ES, Brażil

Received on 02.23.2016 - Desk acceptance on 03.26.2016 - $3^{\text {rd }}$ version approved on 11.21 .2016

\begin{abstract}
This study evaluates the effects of the audit committee and the fiscal council with their different characteristics on earnings quality in Brazil. The proxies of earnings quality used are: relevance of accounting information, timeliness, and conditional conservatism. The sample consists of Brazilian companies listed on the Brazilian Securities, Commodities, and Futures Exchange (BM\&FBOVESPA) with annual liquidity above 0.001 within the period from 2010 to 2013. Data were collected from the database Comdinheiro and the Reference Forms of companies available on the website of the Brazilian Securities and Exchange Commission (CVM) or the BM\&FBOVESPA. The samples used in the study totaled 718, 688, and 722 observations for the value relevance, timeliness, and conditional conservatism models, respectively. The results indicate that different arrangements of the fiscal council and the existence of the audit committee differently impact the accounting. information properties. The presence of the fiscal council positively impacted the relevance of equity, while the presence of the audit committee, the relevance of earnings. Conditional conservatism is evidenced in the group of companies with a permanent fiscal council, demonstrating that it is significant as a governance mechanism, rather than the installation for temporary operation when asked by shareholders in an ordinary general meeting. The presence of both showed significant earnings for the market, but they were not timely, something which exposes restriction to the relevance found. Lastly, the powered fiscal council showed a positive association only concerning the relevance of equity.
\end{abstract}

Keywords: earnings quality, fiscal council, audit committee, corporate governance, powered fiscal council. 


\section{INTRODUCTION}

The quality of accounting figures is intrinsically linked to the quality of corporate governance (Sloan, 2001). Accounting provides information, among other aspects, concerning executives' performance that are needed by most corporate governance mechanisms to effectively operate in addressing agency problems (Bushman \& Smith, 2001; Sloan, 2001).

Previous studies have shown that the board of directors and its structure and composition, as well as that of its committees, affect the quality of accounting figures, indicating that good corporate governance practices benefit shareholders (Trapp, 2009; Vafeas, 2000; Xie, Davidson \& Dadalt, 2003). In addition, the efforts to grasp the function of the audit committee, an advisory body of the board of directors directly responsible for the supervision of accounting processes (Instituto Brasileiro de Governança Corporativa [IBGC], 2009, 2010; U.S. Government, 2002) have also increased.

Brazil has a characteristic different from other countries due to the potential presence of the fiscal council in companies, according to Law 6,404/1976, the so-called Brazilian Corporate Law (Brasil, 1976). It is a body that can be set up and have its members elected at a shareholders' general meeting as an instrument to inspect the managers' acts. Among its functions, the fiscal council is responsible for examining and commenting on the financial statements audited by an external auditor (Brasil, 1976; IBGC, 2010).

In the Brazilian environment, we may ponder that both the board of directors and its committees and the fiscal council have functions that aim at reducing information asymmetry, something which can improve the quality of information disclosed to the market, in addition to provide more efficient monitoring of executives. These bodies can contribute to reduce the agency conflicts highlighted by Jensen and Meckling (1976).

Studies such as Ahmed and Henry (2012), Baxter and Cotter (2009), and Wild (1996) have provided evidence that the audit committee improves the quality of accounting figures. In Brazil, Trapp (2009) argues that the fiscal council is related to lower levels of earnings management.

In this way, investigating and understanding the relation between functions of the fiscal council and the audit committee and earnings quality has proved to be a research opportunity poorly addressed by literature and convenient to the Brazilian environment. Also, the Securities and Exchange Commission (SEC), as a consequence of the Sarbanes-Oxley Act (SOX) (U.S. Government, 2002), which provided for mandatory implementation of an audit committee, authorized the Brazilian companies holding American Depositary Receipts (ADRs) listed on the New York Stock Exchange (NYSE) to structure corporate governance, considering the fiscal council with an overlap to the audit committee, i.e. it is up to the fiscal council to adapt, also taking the functions of this committee, becoming the so-called 'powered fiscal council.'

The audit committee and the fiscal council have common functions related to the generation and reporting of accounting information, but they are different in many ways, emerging discussions about the establishment of one or the other. The same applies to the implementation of the powered fiscal council (Furuta \& Santos, 2010; PricewaterhouseCoopers [PwC], 2007).

The two bodies should not be regarded as mutually excluding, since their functions, responsibilities, hierarchy, and composition are different. First, they occupy different hierarchical positions in the organization: the audit committee is subordinate to the board of directors, preferably formed by independent representatives of this, while the fiscal council is autonomous and not linked to any management body, it consists of shareholders' representatives. In this way, the independence rules are also different from each other; regarding the functions and competences, the audit committee is delegated with activities specific to the 'management' function, and the fiscal council is an institutional tool of the shareholders' right to exert control over management (Furuta \& Santos, 2010; PwC, 2007). In this way, adopting the two bodies in the same organization could contribute to greater transparency in managers' actions and better corporate governance practices (Santos, 2009).

Thus, considering the corporate governance environment in the Brazilian capital market, this study investigates the following research question: what are the effects of the audit committee and the fiscal council on earnings quality of public companies listed on the BM\&FBOVESPA?

This study aims to evaluate the effects of the audit committee and the fiscal council and their different arrangements - types of fiscal council (when it exists, either as permanent or temporary), permanent, temporary, or powered fiscal council - on earnings quality in Brazil.

As proxies to measure earnings quality, the relevance, timeliness, and conditional conservatism models were 
adopted, according to Almeida (2010), Barth, Landsman and Lang (2008), and Lopes and Walker (2008).

The contribution of this research lies on the fact that there is an extensive international literature on earnings quality and its relation with corporate governance mechanisms, unlike the Brazilian reality. Also, the Brazilian literature is incipient to consolidate the understanding of the relation between the audit committee and the fiscal council with financial statement quality. Finally, this research brings as a differential feature to the international literature the inclusion of the fiscal council as a mechanism of corporate governance and its interactions with earnings quality.

The results indicate different effects of the bodies under analysis on earnings quality proxies. The fiscal council, in general, either permanent or temporary, has positive association with the book value relevance and the audit committee with net income. At the same time, the results for companies that have permanently installed fiscal councils show that both the relevance of equity and net income is increased, as well as the timely recognition of economic losses (conditional conservatism), demonstrating the importance of permanent installation of the fiscal council to control financial report. The firms with a powered fiscal council showed relevance only for equity among all the earnings quality metrics used, something which contributes to the existing discussion between scholars and professionals about the loss of focus on the attributions of this body: for instance, PwC (2007).

This study is divided, after this Introduction, as follows: 2. Theoretical framework and development of hypotheses; 3 . Methodology, where models' details, sample development, and estimators are presented; 4 . Analysis of results by each model and their variations; 5 . Robustness analysis; and 6. Final remarks.

\section{THEORETICAL FRAMEWORK AND DEVELOPMENT OF HYPOTHESES}

Bushman and Smith (2001) argue that corporate governance mechanisms are the means by which controlling agents are disciplined to act in accordance with investors' interests. Accounting is a part of the set of corporate governance mechanisms, as it promotes greater transparency regarding the financial performance of firms within a period and the dissemination of this information aims to reduce information asymmetry and agency problems (Bushman, Chen, Engel \& Smith, 2004).

There is no precise and fully reliable metric in the literature to measure earnings quality, as discussed by Dechow, Ge and Schrand (2010), but researchers have developed over the years several models that seek to capture different properties of accounting figures.

Almeida (2010), Barth et al. (2008), and Lopes and Walker (2008) used similar properties to measure earnings quality, such as relevance, timeliness, and conditional conservatism, the same used in this study.

\subsection{Audit Committee}

The audit committee is an advisory body of the board of directors consisting, preferably, of independent board members. It assures to the board of directors the control over earnings quality and internal controls, and it is regarded as an essential mechanism in corporate governance (IBGC, 2009).

The concept of audit committee is not new. Since 1939 and 1940, the NYSE and the SEC, respectively, recommend setting up audit committees as a response to the case McKesson and Robbins in the late 1930s. In subsequent years, the number of companies with established committees significantly increased and the U.S. Congress, the SEC, accountants, and others expressed interest and support for this body (Birkett, 1986).

The NYSE and National Association of Securities Dealers Automated Quotations (NASDAQ) established, in 1978 and 1989, respectively, as requirements for listing on their stock exchanges, the establishment of an audit committee consisting of fully independent members. In 1999, they jointly developed the Blue Ribbon Committee on Improving the Effectiveness of Corporate Audit Committees, with the purpose of making recommendations on the composition and operation of audit committees, subsequently adopted by the SEC.

The audit committee gained prominence worldwide after the U.S. scandals, mainly involving Enron and WorldCom, which prompted the SOX enactment by the U.S. Congress, in July 2002. The SOX introduced corporate governance rules, among others, aiming to ensure greater transparency to financial reporting by the companies, also instituting mandatory establishment of this committee.

In Brazil, Law 6,404/1976 (Brasil, 1976) does not deal with the audit committee, but it regulates the general board of directors. In the country, the installation of a committee is not mandatory, except for financial institutions and insurance companies, according to regulation by the National Monetary Council (CMN), the Central Bank 
of Brazil (BACEN), and the National Council of Private Insurance (CNSP).

Accordingly, the audit committee has the function of inspecting the financial reporting process (internal process management and integrity and effectiveness of internal controls) and internal and external audit, including the resolution of conflicts between executives and auditor.

The committee ensures the integrity and timeliness of financial information, as well as the interests of shareholders and other stakeholders (IBGC, 2010; U.S. Government, 2002). Therefore, its activities are closely related to the financial reporting quality (Klein, 2002; He, Labelle, Piot \& Thornton, 2009).

In Brazil, research addressing the influence of an audit committee as a governance mechanism on earnings quality is incipient, we may highlight Cunha, Hillesheim, Faveri and Rodrigues (2014) and Filipin (2012).

Cunha et al. (2014) investigated whether characteristics of the audit committee (size, expertise, and independence) reflect on earnings management by Brazilian public companies listed on the BM\&FBOVESPA and they concluded that none of the characteristics under study impacted on earnings management.

Using a portfolio of proxies to measure earnings quality, as in this study, Filipin (2012) sought to verify whether companies with an audit committee listed on the BM\&FBOVESPA have better earnings quality; the results for these companies suggested greater relevance of accounting information, but less conservative and persistent net income.

The international literature is extensive and the authors generally share the same hypothesis about improving financial reporting quality (Chtourou, Bédard \& Courteu, 2001; Felo, Krishnamurthy \& Solieri, 2003; Xie et al., 2003).

Before the audit committee became mandatory in the United States of America (USA), Dechow, Sloan and Sweeney (1996) found evidence that companies that manage their earnings were less likely to have this committee installed than other firms. Wild (1996) noticed the reaction of the U.S. market to the release of financial statements before and after the establishment of an audit committee and found that the market reaction to disclosure of financial statements after the establishment of a committee is greater than in previous periods.

Ahmed and Henry (2012) and Baxter and Cotter (2009) investigated, in Australian companies, whether voluntary installation of the audit committee impacted the earnings quality. Baxter and Cotter (2009) found evidence of reduced earnings management practices, while Ahmed and Henry (2012) showed a positive impact on unconditional conservatism and a negative impact on conditional conservatism. In this context, the first research hypothesis on the presence of an audit committee in companies listed on the BM\&FBOVESPA is presented:

$\mathrm{H}_{1}$ : the audit committee enhances the financial reporting quality.

\subsection{Fiscal Council}

In Brazil, the fiscal council is an organ provided for in Law 6,404/1976 (Brasil, 1976) and the company's statute will provide for its operation, which may be permanent or installed by the general meeting at shareholders' request. When installed, it must consist of at least 3 and at most 5 members and substitutes in equal numbers, shareholders or not (Brasil, 1976).

The fiscal council is a body independent from the company's board and executives and its competences are set in article 163 of Law 6,404/1976 (Brasil, 1976), i.e. it reports directly to the shareholders at the meetings. This body inspects the actions taken by the company's board and board of directors, comments on proposals by administration bodies, as well as it examines and comments on the financial statements audited by the external audit, seeking to preserve shareholders' rights.

Both the IBGC, from a professional perspective, and scholars (Carvalhal-da-Silva \& Leal, 2005; Tinoco, Escuder \& Yoshitake, 2011; Trapp, 2009), regard the fiscal council as a part of the corporate governance system in Brazil. The fact that the fiscal council is a direct representative of shareholders inspecting executives' management can have a great influence on the reduction of agency conflict and informational asymmetry, something which makes it a significant control mechanism. Also, Tinoco et al. (2011) claim that the fiscal council collaborates with those who are far from control and power (especially minority shareholders).

Trapp (2009) sought to evaluate the direct intersection of a fiscal council as a good corporate governance practice to reduce earnings management. Evidence indicates that these factors, considering the existence and qualification of the members of a fiscal council, are related to lower levels of discretionary accruals.

Finally, Carvalhal-da-Silva and Leal (2005) claim, when constructing the Corporate Governance Index, that the existence of a permanent fiscal council in the organization is more effective to monitor and arrange company's management than the council installed only at shareholders' request. It is assumed that a fiscal council installed regardless of shareholders' will and on a continued basis provides the company with greater 
power from this mechanism in the corporate governance system, mainly by increasing earnings quality.

In this context, the second research hypothesis on the presence of a fiscal council in companies listed on the BM\&FBOVESPA is presented:

$\mathrm{H}_{2}$ : the fiscal council enhances earnings quality.

Additionally, to analyze the second hypothesis, we investigate on a methodological basis the various fiscal council arrangements (permanent and temporary).

\subsection{Powered Fiscal Council}

An imposition of the SOX was mandatory installation of the audit committee in companies listed on all the U.S. stock exchanges, something which also affected foreign companies that issue ADRs in the U.S. market (Furuta \& Santos, 2010). In the Brazilian case, after an agreement between the Brazilian Securities and Exchange Commission (CVM) and the SEC, in 2003, mandatory installation of the audit committee was abolished if the company used the fiscal council, adapting it to the functions of a committee, so that the fiscal council incorporates new responsibilities and functions (hereafter, powered fiscal council).

According to the IBGC (2009), considering the legal attributions of the fiscal council provided for in Law 6,404/1976 (Brasil, 1976), the possibility that this body takes any administration activity is excluded. The creation of a powered fiscal council does not contradict this understanding, since the fiscal council is careful not to act as an advisor or assessor concerning management decisions. Accordingly, certain activities that cannot be delegated by the board of directors or executives, such as hiring audit and 'non-audit' services, should not be assigned to the fiscal council, since they are provided for by article 142 of Law 6,404/1976 (Brasil, 1976) as duties of the board of directors.

PwC (2007) discusses the strengths and weaknesses of adopting a powered fiscal council. According to this study, opponents argue that the fiscal council is an institutional tool to exert shareholders' inspection does not serve the purpose of the audit committee to be a management instrument of the board of directors. In addition, the fiscal council has functions and duties different from those predicted for the audit committee, such as providing opinions on proposals to change company's capital, issue debentures, investment plans, or capital budgets, among others, something which can lead to loss of focus on specific attributions of the audit committee.

According to Santos (2009), many Brazilian companies that issue ADRs still prefer to strictly comply with the SOX requirements and not install the powered fiscal council; this is most likely due to a market-driven and strategic issue of making their stocks available in the U.S. market, since the acquirer of these stocks is more familiar with the audit committee than with any other type of monitoring body. However, Calazans (2003) highlights that the constitution of an audit committee in Brazilian companies might increase their cost and this additional cost can often be higher than the benefit generated.

Furuta and Santos (2010) investigated the perspective of executives from companies operating in Brazil and issuing ADRs and that of market analysts concerning the formation of an audit committee or a powered fiscal council. The results indicated there was no consensus of opinion that the fiscal council is more adaptable than the audit committee to the Brazilian business environment if the functions of these bodies are different and if the costs associated with committee formation are relevant.

It is assumed, then, that the fiscal council improves earnings quality, since it absorbs, in addition to the legal functions of the fiscal council, the functions of the audit committee, expanding its scope of action. Also, companies with a powered fiscal council are listed on the U.S. stock exchanges, something which indicates greater rigor in corporate governance. Thus, the third research hypothesis is presented:

$\mathrm{H}_{3}$ : the powered fiscal council improves the financial reporting quality. 


\subsection{Audit Committee and Fiscal Council}

The fiscal council and the audit committee occupy different hierarchical positions in the organization: the second is subordinate to the board of directors, preferably consisting of independent members, while the first is set up by the general meeting, a body which represents controlling shareholders and minority shareholders. Unlike the committee, the fiscal council is autonomous and is not linked to any organization's body, and it must report to the shareholders directly at the meetings.

The bodies also have differences in their functions and duties. Audit committees are delegated with activities inherent to the 'management' function, i.e. it is an advisory mechanism made available to the board of directors to fulfill its tasks. Among the legal attributions of the fiscal council, the possibility of exercising any activity inherent to management is excluded. The council activities are carried out according to the role of wide and unrestricted inspection of managers' legal and statutory duties, at shareholders' request, as a decision of the general meeting. In this way, it is an institutional mechanism to exert the shareholders' right of control on the executive's decision (IBGC, 2009; PwC, 2007).

Among the differences between these bodies that may directly interfere with accounting information, we highlight the fact that the functions of an audit committee are more specific and focused on the financial reporting process, unlike the fiscal council, which besides recommending whether the financial statements can be approved also inspects the managers' acts.

Each body has its function in the hypothesis of enhancing financial reporting quality, either advising the board of directors (audit committee) or inspecting and reporting to the shareholders (fiscal council). In this way, the acceptance of both bodies in the same organization refers to the reasoning that they are not mutually excluding. This trend might lead to greater transparency of managers' actions and adoption of better corporate governance practices, since a large number of views on control coexisting in the same environment could contribute to ensure continuity in the organization, regardless of individual or group interests (Santos, 2009).

Based on the assumption that better corporate governance practices in the organization improve the quality of financial reporting, it is expected that adopting the two bodies has a positive impact on this relation. Thus, the fourth research hypothesis is:

$\mathrm{H}_{4}$ : the presence of the audit committee and the fiscal council, simultaneously, enhances earnings quality.

\section{METHODOLOGY}

The study population comprises active publiclytraded corporations listed on the BM\&FBOVESPA that have data available for the period within 2010 and 2013. To start constructing the sample, only companies with annual liquidity above 0.001 were selected. Financial institutions and funds were excluded from the sample, because they have a specific accounting standard and regulation. Observations with empty cells, with values equal to 0 , and errors in the variables of interest of each model, as well as the companies that did not provide the Reference Form, were also excluded.

The accounting and market data were obtained from the database Comdinheiro. Information on the fiscal council and the audit committee was obtained from the company Reference Forms, available at the websites of the BM\&FBOVESPA and the CVM.

Earnings quality models were estimated using the ordinary least squares (OLS) method, with robust standard errors clustered by firm. This estimation method has been widely used in accounting and finance studies (Almeida, 2010; Giroud \& Mueller, 2010; Lopes \& Walker, 2008).

As a method to exclude outliers, observations with extreme values above 3 standard deviations from the standardized mean value of each variable were excluded. Table 1 shows how observations were filtered, resulting in the final study sample by model. 
Table 1 Sample selection

\begin{tabular}{|c|c|c|c|}
\hline & Relevance & Timeliness & Conservatism \\
\hline Initial database (4 years) & 1,592 & 1,592 & 1,592 \\
\hline (-)Annual liquidity below 0.001 & $(713)$ & $(713)$ & $(713)$ \\
\hline (-)Financial institutions and funds & $(91)$ & $(91)$ & $(91)$ \\
\hline (-)Companies that did not provide RF & $(10)$ & $(10)$ & (10) \\
\hline (=)Sample with outliers & 778 & 778 & 778 \\
\hline (-)Empty cells (by model) & $(32)$ & $(54)$ & $(32)$ \\
\hline (-) Outliers (by model) & (28) & (36) & (24) \\
\hline (=) Final sample & 718 & 688 & 722 \\
\hline
\end{tabular}

$R F=$ Company Reference Forms.

Source: Prepared by the authors.

Since there is no single way to measure earnings quality, this study was based on the metrics used by Lopes and Walker (2008), which capture earnings quality, based on its properties, among them relevance, timeliness, and conditional conservatism. It is believed, therefore, that more relevant accounting figures, greater timely loss recognition (bad news), and more timely information correspond to better financial reporting process.

The model that tests the value relevance considers the information content of net income and book value as a function of share price.

This study evaluates the effect of the existence of a fiscal council in Brazilian companies and its variations: general fiscal council (when it exists, either on a permanent or temporary basis), permanent, temporary, or powered fiscal council, audit committee, of both organs simultaneously and one or the other on relevance. All these combinations are controlled by dummy variables in alternate models. To do this, model 1 was prepared, which has dummy variables and control variables $(\mathrm{CV})$, as follows:

$$
P_{i, t}=\beta_{0}+\beta_{1} \cdot N I_{i, t}+\beta_{2} \cdot B V_{i, t}+\beta_{3} \cdot C_{n}+\beta_{4} \cdot N I_{i, t}{ }^{*} C_{n}+\beta_{5} \cdot B V_{i, t}{ }^{*} C_{n}+\sum_{1}^{n} \cdot \beta_{n} \cdot \text { Control }+\varepsilon_{i, t}
$$

where: $P_{i, t}$ is the share price of company $i$ in year $t$ adjusted by dividends and splits (four months after the end of the year) and scaled by share price in $t-1, N I_{i, t}$ is earnings per share of company $i$ in year $t$ scaled by share price in $t-1, B V_{i, t}$ is equity per share of company $i$ in year $t$, scaled by share price in $t-1 i, C_{n}$ is the variable that takes value 1 for $F C_{n}, A C, A C F C$ or $A C O F C$ [where: $F C_{n}=$ dummy variable if firm $i$ has a general fiscal council installed $\left(F C_{1}\right)$, a permanent fiscal council $\left(F C_{2}\right)$, or a powered fiscal council $\left(\mathrm{FC}_{3}\right) ; A C=$ dummy variable if firm $i$ has an audit committee installed; ACFC = dummy variable if firm $i$ has both, fiscal council and audit committee installed; ACOFC = dummy variable if firm $i$ has a fiscal council or an audit committee installed] in each dummy, otherwise it is considered as 0 .

The CVs used in this research were firm size $(S)$, leverage ( $L E V$ ), and growth opportunity (GRO) measured by the natural logarithm of total assets, total debt divided by total assets, and percentage growth of net revenues, respectively.

Lopes (2009) states that net income can influence price over a long period of time. Thus, the model to test timeliness aims at revealing whether net income and its variation can explain stock return. Model 2 is presented below, it has been developed in this research, which sought to identify the effect on timeliness.

$$
R_{i, t}=\beta_{0}+\beta_{1} \cdot N I_{i, t}+\beta_{2} \cdot \Delta N I_{i, t}+\beta_{3} \cdot C_{n}+\beta_{4} \cdot N I_{i, t}{ }^{*} C_{n}+\beta_{5^{*}} \cdot \Delta N I_{i, t}{ }^{*} C_{n}+\sum_{1}^{n} \cdot \beta_{n} \cdot \text { Control }+\varepsilon_{i, t}
$$


where: $R_{i, t}$ is return on (the most liquid class) share of company $i$ in year $t$ adjusted by dividends and splits (four months after the end of the year) and scaled by share price in $t-1, N I_{i, t}$ is earnings per share of company $i$ in year $t$ and scaled by share price in $t-1$, and $\Delta B V_{i, t}$ are changes in net income per share of company $i$ in year $t$ and scaled by share price in $t-1\left(C_{n}\right.$ according to model 1$)$.
The conditional conservatism model used is that developed by Basu (1997). The model is based on the concept that net income is, in its nature, conservative in a conditional sense (asymmetric recognition between losses and gains) and it anticipates bad news in relation to good news. The model relates net income to stock return. Model 3 is presented below:

$N I_{i, t}=\beta_{0}+\beta_{1} \cdot D_{i, t}+\beta_{2} \cdot R_{i, t}+\beta_{3} \cdot R_{i, t}{ }^{*} D_{i, t}+\beta_{4} \cdot C_{n}+\beta_{5} \cdot D_{i, t}{ }^{*} C_{n}+\beta_{6} \cdot R_{i, t}{ }^{*} C_{n}+\beta_{7} \cdot R_{i, t}{ }^{*} D_{i, t}{ }^{*} C_{n}+\sum_{1}^{n} \cdot \beta_{n} \cdot$ Control $+\varepsilon_{i, t}$

where: $N I_{i, t}$ is the earnings per share of company $i$ in year $t$, scaled by share price at $t-1, D_{i, t}$ is the dummy for return, i.e. 1 for negative return and 0 for positive return of company $i$ in year $t$, and $R_{i, t}$ is return on share (the most liquid share class) of company $i$ in year $t$ adjusted by dividends and splits (four months after the end of the year) and scaled by share price at $t-1\left(C_{n}\right.$ according to model 1$)$.
It is expected that the coefficients of variables of interest from interactions with variables related to the existence of the fiscal council, audit committee, both of them, one or the other, permanent fiscal council and powered fiscal council are positive and statistically significant in all models.

\section{ANALYSIS OF RESULTS}

Table 2 shows sample composition according to the existence of the bodies under analysis. The results are presented for the total sample (annual stock liquidity above 0.001 ) without excluding outliers.

Table 2 Global composition of the fiscal council and the audit committee in Brazil between 2010 and 2013

\begin{tabular}{|c|c|c|c|c|c|}
\hline Bodies/observations & 2010 & 2011 & 2012 & 2013 & 2010-2013 \\
\hline Audit Committee & 61 & 61 & 65 & 67 & 254 \\
\hline Fiscal council & 111 & 109 & 117 & 120 & 457 \\
\hline Permanent fiscal council & 48 & 47 & 47 & 46 & 188 \\
\hline Temporary fiscal council & 63 & 62 & 70 & 74 & 269 \\
\hline Powered fiscal council & 9 & 10 & 9 & 10 & 38 \\
\hline Permanent powered fiscal council & 9 & 9 & 8 & 7 & 33 \\
\hline Temporary powered fiscal council & 0 & 1 & 1 & 3 & 5 \\
\hline Fiscal council and audit committee & 34 & 33 & 36 & 38 & 141 \\
\hline Permanent fiscal council and audit committee & 19 & 18 & 22 & 22 & 81 \\
\hline Temporary fiscal council and audit committee & 15 & 15 & 14 & 16 & 60 \\
\hline None & 53 & 60 & 46 & 49 & 208 \\
\hline Observations & 191 & 197 & 192 & 198 & 778 \\
\hline
\end{tabular}

Source: Prepared by the authors.

It is verified that the most common practice in Brazil is adopting a fiscal council, since 457 observations (companies-year) had this body installed within the four years surveyed. The presence of a powered fiscal council is noticed in 38 observations of the sample and it corresponds to companies that issue ADR and did not install the audit committee.

In Brazil, the installation of an audit committee is voluntary, except for financial institutions and insurance companies, so that its existence is found in 254 observations. There are 208 observations from firms that have neither installed a fiscal council or an audit 
committee, something which may suggest weakness in the corporate governance system and lower monitoring of managers in these companies.
Table 3 displays the descriptive statistics of variables in the earnings quality models explained in the methodology.

Table 3 Descriptive statistics of earnings quality models

\begin{tabular}{|c|c|c|c|c|c|c|}
\hline Variables & Observations & Mean value & Median & Standard deviation & Minimum & Maximum \\
\hline \multicolumn{7}{|c|}{ Relevance model } \\
\hline$P$ & 718 & 1.004 & 0.980 & 0.378 & 0.063 & 2.155 \\
\hline NI & 718 & -0.024 & 0.051 & 0.485 & -5.072 & 1.905 \\
\hline$B V$ & 718 & 0.553 & 0.619 & 1.856 & -23.580 & 9.405 \\
\hline$S$ & 718 & 15.020 & 15.029 & 1.560 & 10.333 & 20.069 \\
\hline$G R O$ & 718 & 0.158 & 0.129 & 0.373 & -2.631 & 3.392 \\
\hline LEV & 718 & 0.631 & 0.578 & 0.422 & 0.009 & 4.341 \\
\hline$F C_{1}$ & 718 & 0.599 & 1 & 0.490 & 0 & 1 \\
\hline$F C_{2}$ & 718 & 0.251 & 0 & 0.434 & 0 & 1 \\
\hline$F C_{3}$ & 718 & 0.051 & 0 & 0.221 & 0 & 1 \\
\hline$A C$ & 718 & 0.340 & 0 & 0.474 & 0 & 1 \\
\hline ACFC & 718 & 0.191 & 0 & 0.393 & 0 & 1 \\
\hline ACOFC & 718 & 0.748 & 1 & 0.434 & 0 & 1 \\
\hline \multicolumn{7}{|c|}{ Timeliness model } \\
\hline$R$ & 688 & 0.001 & -0.001 & 0.288 & -2.457 & 3.112 \\
\hline $\mathrm{NI}$ & 688 & -0.018 & 0.053 & 0.489 & -5.072 & 1.905 \\
\hline$\Delta \mathrm{N} I$ & 688 & -0.027 & 0.002 & 0.464 & -4.634 & 3.508 \\
\hline$S$ & 688 & 15.060 & 15.040 & 1.511 & 10.471 & 20.069 \\
\hline GRO & 688 & 0.159 & 0.130 & 0.366 & -2.631 & 3.392 \\
\hline LEV & 688 & 0.626 & 0.576 & 0.422 & 0.009 & 4.341 \\
\hline$F C_{1}$ & 688 & 0.610 & 1 & 0.488 & 0 & 1 \\
\hline$F C_{2}$ & 688 & 0.254 & 0 & 0.436 & 0 & 1 \\
\hline$F C_{3}$ & 688 & 0.053 & 0 & 0.226 & 0 & 1 \\
\hline$A C$ & 688 & 0.340 & 0 & 0.474 & 0 & 1 \\
\hline ACFC & 688 & 0.192 & 0 & 0.394 & 0 & 1 \\
\hline ACOFC & 688 & 0.759 & 1 & 0.428 & 0 & 1 \\
\hline \multicolumn{7}{|c|}{ Conservatism model } \\
\hline $\mathrm{NI}$ & 722 & -0.023 & 0.051 & 0.484 & -5.072 & 1.905 \\
\hline$R$ & 722 & -0.010 & -0.001 & 0.393 & -4.035 & 4.000 \\
\hline$D$ & 722 & 0.514 & 1 & 0.500 & 0.000 & 1.000 \\
\hline$S$ & 722 & 15.018 & 15.023 & 1.546 & 10.471 & 20.069 \\
\hline GRO & 722 & 0.160 & 0.130 & 0.373 & -2.631 & 3.392 \\
\hline LEV & 722 & 0.630 & 0.577 & 0.422 & 0.009 & 4.341 \\
\hline$F C_{1}$ & 722 & 0.601 & 1 & 0.490 & 0 & 1 \\
\hline$F C_{2}$ & 722 & 0.252 & 0 & 0.435 & 0 & 1 \\
\hline$F C_{3}$ & 722 & 0.051 & 0 & 0.220 & 0 & 1 \\
\hline$A C$ & 722 & 0.338 & 0 & 0.473 & 0 & 1 \\
\hline ACFC & 722 & 0.190 & 0 & 0.392 & 0 & 1 \\
\hline ACOFC & 722 & 0.749 & 1 & 0.434 & 0 & 1 \\
\hline
\end{tabular}

Note: $P_{i, t}$ is the share price of company $i$ in year $t$ adjusted by dividends and splits (four months after the end of the year) and scaled by share price in $t-1, N I_{i, t}$ is earnings per share of company $i$ in year $t$ scaled by share price in $t-1, B V_{i, t}$ is equity per share of company $i$ in year $t$, scaled by share price in $t-1, R$ is annual return of firm $i$ in period $t$ (four months after the beginning of the year), and $\triangle \mathrm{NI}_{i t}$ is profit variance per share of firm $i$ in period $t$. The variables $P, L P A, P L A, R, \triangle L P A$ are scaled by price in $t-1$ (four months after the beginning of the year).

$A C F C=$ dummy variable if firm $i$ has both, fiscal council and audit committee, installed; $A C=$ dummy variable if firm $i$ has an audit committee installed; $F C_{n}=$ dummy variable if firm $i$ has a general fiscal council installed ( $F C_{1}$ ), a permanent fiscal council $\left(F C_{2}\right)$, or a powerful fiscal council $\left(F C_{3}\right) ; D=$ dummy variable, considering 1 if the return is negative and 0 , otherwise; $L E V=$ leverage of firm $i$ in period $t$; GRO = revenue growth of firm $i$ in period $t$; ACOFC =dummy variable if firm $i$ has a fiscal council or an audit committee installed; $S=$ natural logarithm of total assets of firm $i$ in period $t$.

Source: Prepared by the authors. 
We observe greater data dispersion between the variables $N I$ and GRO in all models, as well as the variables $R$ and $\Delta N I$ in the timeliness model and $R$ in conditional conservatism, since they have a standard deviation above mean value. For the variables body presence and arrangement, extreme values (minimum and maximum value) are always the same, due to the characteristics of these variables, but they have differences in dispersion between the various variables.

Table 4 shows the results referring to regressions for the relevance model.

Table 4 Results of the relevance model

\begin{tabular}{|c|c|c|c|c|c|c|}
\hline \multicolumn{7}{|c|}{$\begin{array}{c}\text { Model } 1 \\
P_{i, t}=\beta_{0}+\beta_{1} \cdot N I_{i, t}+\beta_{2} \cdot B V_{i, t}+\beta_{3} \cdot C_{n}+\beta_{4} \cdot N I_{i, t}^{*} C_{n}+\beta_{5} \cdot B V_{i, t}{ }^{*} C_{n}+\sum_{1}^{n} \cdot \beta_{n} \cdot \text { Control }+\varepsilon_{i, t}\end{array}$} \\
\hline Column & 1 & 2 & 3 & 4 & 5 & 6 \\
\hline \multirow[t]{2}{*}{ Variables } & $\begin{array}{c}\text { General fiscal } \\
\text { council }\end{array}$ & $\begin{array}{c}\text { Audit } \\
\text { Committee }\end{array}$ & Both & $\begin{array}{l}\text { Fiscal council or } \\
\text { audit committee }\end{array}$ & $\begin{array}{l}\text { Permanent fiscal } \\
\text { council }\end{array}$ & $\begin{array}{c}\text { Powered fiscal } \\
\text { council }\end{array}$ \\
\hline & $\mathrm{C}=\mathrm{FC}_{1}$ & $\mathrm{C}=\mathrm{AC}$ & $\mathrm{C}=\mathrm{ACFC}$ & $\mathrm{C}=\mathrm{ACOFC}$ & $\mathrm{C}=\mathrm{FC}_{2}$ & $\mathrm{C}=\mathrm{FC}_{3}$ \\
\hline \multirow{2}{*}{ NI } & $0.285^{* * *}$ & $0.180^{* * *}$ & $0.199 * * *$ & $0.239 * * *$ & $0.204^{* * *}$ & $0.225^{* * *}$ \\
\hline & $(5.20)$ & $(3.41)$ & $(3.56)$ & $(4.48)$ & (3.59) & $(3.76)$ \\
\hline \multirow{2}{*}{$B V$} & $-0.0422^{* * *}$ & $-0.0217^{* *}$ & $-0.0239^{* * *}$ & $-0.0366^{* * *}$ & $-0.0288^{* * *}$ & $-0.0306^{* * *}$ \\
\hline & $(-5.50)$ & $(-2.54)$ & $(-2.82)$ & $(-4.25)$ & $(-3.31)$ & $(-3.69)$ \\
\hline \multirow{2}{*}{$C_{n}$} & 0.0479 & 0.0296 & $0.107^{*}$ & 0.0440 & $-0.0706^{*}$ & -0.0508 \\
\hline & $(0.132)$ & $(0.67)$ & $(1.82)$ & 1.29 & $(-1.92)$ & $(-0.68)$ \\
\hline \multirow{2}{*}{$N I^{*} C_{n}$} & -0.104 & $0.568^{* * *}$ & $0.382^{* * *}$ & -0.0328 & $0.431^{* * *}$ & -0.150 \\
\hline & $(-1.16)$ & $(4.08)$ & (3.08) & $(-0.35)$ & $(3.57)$ & $(-0.74)$ \\
\hline \multirow{2}{*}{$B V^{*} C_{n}$} & $0.0281^{* *}$ & 0.00306 & -0.0314 & $0.0206^{*}$ & $0.0902^{* * *}$ & $0.0568^{* *}$ \\
\hline & $(2.60)$ & $(0.06)$ & $(-0.51)$ & $(1.76)$ & (3.48) & $(2.51)$ \\
\hline \multirow{2}{*}{$S$} & 0.00479 & 0.00603 & 0.00378 & 0.00514 & 0.00306 & 0.00978 \\
\hline & $(0.50)$ & (0.63) & (0.39) & $(0.54)$ & $(0.29)$ & (0.93) \\
\hline \multirow{2}{*}{ GRO } & $0.106^{* *}$ & $0.0837^{*}$ & $0.0948^{* *}$ & $0.102^{* *}$ & $0.0968^{* *}$ & $0.0982^{* *}$ \\
\hline & $(2.20)$ & $(1.81)$ & $(2.01)$ & $(2.01)$ & $(2.04)$ & $(2.04)$ \\
\hline \multirow{2}{*}{ LEV } & $-0.104^{* * *}$ & $-0.104 * * *$ & $-0.105^{* * *}$ & $-0.102^{* * *}$ & $-0.109 * * *$ & $-0.109^{* * *}$ \\
\hline & $(-2.92)$ & $(-2.99)$ & $(-2.95)$ & $(-2.91)$ & $(-3.02)$ & $(-2.92)$ \\
\hline \multirow{2}{*}{ Const. } & $0.969^{* * *}$ & $0.968^{* * *}$ & $0.998^{* * *}$ & $0.958^{* * *}$ & $1.026^{* * *}$ & $0.932^{* * *}$ \\
\hline & $(6.51)$ & (6.39) & $(6.51)$ & $(6.47)$ & $(6.06)$ & (5.57) \\
\hline $\mathrm{R}^{2}(\%)$ & 10.98 & 12.5 & 11.47 & 10.39 & 11.82 & 10.32 \\
\hline $\mathrm{F}$ & 6.45 & 9.66 & 9.57 & 5.21 & 10.44 & 9.75 \\
\hline Prob. F & 0.000 & 0.000 & 0.000 & 0.000 & 0.000 & 0.000 \\
\hline Clusters (n) & 210 & 210 & 210 & 210 & 210 & 210 \\
\hline Observations & 718 & 718 & 718 & 718 & 718 & 718 \\
\hline
\end{tabular}

Note: $P_{i, t}$ is the share price of company $i$ in year $t$ adjusted by dividends and splits (four months after the end of the year) and scaled by share price in $t-1, N I_{i, t}$ is earnings per share of company $i$ in year $t$ scaled by share price in $t-1, B V_{i, t}$ is equity per share of company $i$ in year $t$, scaled by share price in $t-1$. The first line shows the coefficients and the second line, the $t$ statistics. Standard error is robust and clustered by firm. The variables P, LPA, and PLA are scaled by price in $t-1$ (four months after the beginning of the year).

ACFC = dummy variable if firm $i$ has both, fiscal council and audit committee, installed; $A C=$ dummy variable if firm $i$ has an audit committee installed; $F C_{n}=$ dummy variable if firm $i$ has a general fiscal council installed ( $F C_{1}$ ), a permanent fiscal council $\left(F C_{2}\right)$, or a powerful fiscal council $\left(F C_{3}\right) ; C_{n}=$ variable that takes values for $F C_{n^{\prime}} A C, A C F C$, or ACOFC; $L E V=$ leverage of firm $i$ in period $t$; $G R O=$ revenue growth of firm $i$ in period $t$; ACOFC $=$ dummy variable if firm $i$ has a fiscal council or an audit committee installed; $S=$ natural logarithm of total assets of firm $i$ in period $t$.

***,**, *: significant at $1 \%, 5 \%$, and $10 \%$, respectively.

Source: Prepared by the authors. 
In column 1 of Table 4 , the result for the effect of presence of a general fiscal council has a positive and significant coefficient only for the variable $B V^{\star} F C_{1}(0.0281$, $t=2.60)$. Thus, when the company chooses to set up the general fiscal council (permanent or temporary), the results suggest that equity is relevant to the market, unlike net income, which has a negative and non-significant coefficient, partly corroborating the results of Trapp (2009), which associates the fiscal council installation in Brazil with lower levels of earnings management.

Column 2 displays the results for the effect of an audit committee on relevance. The results are contrary to those of the general fiscal council - the variable $N I^{\star} A C$ has a positive and significant coefficient of $0.568(t=4.08)$-, suggesting that the presence of this control mechanism has a positive impact on relevance of the reported net income. Interaction with the variable $B V$ is positive, but not significant. These results corroborate those of Filipin (2012) in Brazil and they are convergent with Baxter and Cotter (2009) and Wild (1996).

The effects of the presence of both (fiscal council and audit committee, simultaneously), represented in column 3 , show a positive and significant coefficient only for the variable $N I^{*} A C F C(0.382, t=3.08)$, highlighting that the implementation of the two bodies, simultaneously, only affects net income. Also, in column 4, the existence of one or other body has an impact on equity relevance, since the variable $B V^{\star} A C O F C$ has a positive and significant coefficient of $0.0206(t=1.76)$.

The effects of a permanent fiscal council are displayed in column 5 . The results suggest for both the variable $\mathrm{NI}^{\star} \mathrm{FC}_{2}$ and $B V^{\star} F C_{2}$ positive and significant coefficients of $0.431(t=3.57)$ and $0.0902(t=3.48)$, respectively. In this way, the presence of the fiscal council on a permanent basis increases the relevance of net income and equity. Such a result confirms that the market recognizes accounting figures as more relevant information, thus of better quality, when there is a permanent presence of a fiscal council in the companies. This finding confirms the claim of Carvalhal-da-Silva and Leal (2005) that permanent fiscal councils may be regarded as stronger governance mechanisms than when they are installed only at shareholders' request.

The results for the effects of the powered fiscal council (column 6) have evidence similar to that from the general fiscal council: positive and significant coefficient only for the variable $B V^{\star} F C_{3}(0.0568, t=2.51)$ and negative for net income, although not significant, showing impact only on equity relevance.

Table 5 displays the results for the timeliness model. 
Table 5 Results of the timeliness model

\section{Model 2}

\begin{tabular}{|c|c|c|c|c|c|c|}
\hline Column & 1 & 2 & 3 & 4 & 5 & 6 \\
\hline \multirow[t]{2}{*}{ Variables } & $\begin{array}{c}\text { General fiscal } \\
\text { council }\end{array}$ & $\begin{array}{c}\text { Audit } \\
\text { committee }\end{array}$ & Both & $\begin{array}{l}\text { Fiscal council or } \\
\text { audit committee }\end{array}$ & $\begin{array}{c}\text { Permanent fiscal } \\
\text { council }\end{array}$ & $\begin{array}{c}\text { Powered fiscal } \\
\text { council }\end{array}$ \\
\hline & $\mathrm{C}=\mathrm{FC}_{1}$ & $\mathrm{C}=\mathrm{AC}$ & $\mathrm{C}=\mathrm{ACFC}$ & $\mathrm{C}=\mathrm{ACOFC}$ & $\mathrm{C}=\mathrm{FC}_{2}$ & $\mathrm{C}=\mathrm{FC}_{3}$ \\
\hline \multirow{2}{*}{ NI } & $0.171^{* *}$ & $0.136^{* * *}$ & $0.136^{* * *}$ & $0.173^{* *}$ & $0.121^{* *}$ & $0.134^{* * *}$ \\
\hline & $(2.17)$ & $(2.77)$ & $(2.82)$ & $(2.10)$ & $(2.59)$ & $(2.85)$ \\
\hline \multirow{2}{*}{$\Delta N I$} & 0.0162 & 0.0143 & 0.0117 & 0.0227 & 0.0129 & 0.00970 \\
\hline & $(0.65)$ & $(0.86)$ & $(0.77)$ & $(0.78)$ & $(0.91)$ & $(0.86)$ \\
\hline \multirow{2}{*}{$C_{n}$} & 0.0228 & 0.00693 & 0.0149 & 0.0299 & -0.0191 & -0.0181 \\
\hline & $(1.17)$ & $(0.64)$ & $(1.58)$ & $(1.13)$ & $(-1.14)$ & $(-0.68)$ \\
\hline \multirow{2}{*}{$N I^{*} C_{n}$} & -0.0585 & -0.0698 & $-0.114 * *$ & -0.0598 & 0.231 & $-0.183^{* * *}$ \\
\hline & $(-0.70)$ & $(-1.13)$ & $(-1.99)$ & $(-0.69)$ & $(1.47)$ & $(-3.59)$ \\
\hline \multirow{2}{*}{$\Delta \mathrm{NI} I^{*} C_{n}$} & -0.00990 & -0.0127 & -0.00454 & -0.0187 & -0.0105 & -0.0172 \\
\hline & $(-0.37)$ & $(-0.68)$ & $(-0.25)$ & $(-0.62)$ & $(-0.63)$ & $(-0.35)$ \\
\hline \multirow{2}{*}{$S$} & 0.00364 & 0.00562 & 0.00545 & 0.00267 & 0.00669 & 0.00737 \\
\hline & $(0.34)$ & $(0.52)$ & $(0.49)$ & $(0.27)$ & $(0.56)$ & $(0.59)$ \\
\hline \multirow{2}{*}{ GRO } & 0.0348 & 0.0323 & 0.0319 & 0.0351 & 0.0258 & 0.0319 \\
\hline & $(1.17)$ & $(1.07)$ & $(1.05)$ & $(1.21)$ & $(0.84)$ & $(1.05)$ \\
\hline \multirow{2}{*}{ LEV } & 0.0632 & 0.0569 & 0.0571 & 0.0652 & 0.0533 & 0.0572 \\
\hline & $(0.94)$ & $(0.89)$ & $(0.89)$ & $(0.97)$ & $(0.84)$ & $(0.89)$ \\
\hline \multirow{2}{*}{ Const. } & -0.109 & -0.123 & -0.121 & -0.105 & -0.131 & -0.146 \\
\hline & $(-0.62)$ & $(-0.69)$ & $(-0.67)$ & $(-0.61)$ & $(-0.68)$ & $(-0.73)$ \\
\hline $\mathrm{R}^{2}(\%)$ & 5.22 & 4.92 & 4.97 & 5.27 & 5.57 & 4.97 \\
\hline $\mathrm{F}$ & 2.58 & 2.68 & 2.75 & 2.53 & 2.75 & 3.44 \\
\hline Prob. F & 0.010 & 0.008 & 0.006 & 0.012 & 0.055 & 0.001 \\
\hline Clusters (n) & 209 & 209 & 209 & 209 & 209 & 209 \\
\hline Observations & 688 & 688 & 688 & 688 & 688 & 688 \\
\hline
\end{tabular}

Note: $R_{i t}$ is return on (the most liquid class) share of company $i$ in year $t$ adjusted by dividends and splits (four months after the end of the year) and scaled by share price in $t-1, N I_{i, t}$ is earnings per share of company $i$ in year $t$ and scaled by share price in $t-1$, and $\triangle B V_{i, t}$ are changes in net income per share of company $i$ in year $t$ and scaled by share price in $t-1$. In the first line there are coefficients and in the second line, the $t$ statistics. Standard error is robust and clustered by firm. The variables $R, L P A$, and $\triangle L P A$ are scaled by price in $t-1$ (four months after the beginning of the year).

$A C F C=$ dummy variable if firm $i$ has both, fiscal council and audit committee, installed; $A C=$ dummy variable if firm $i$ has an audit committee installed; $F C_{n}=$ dummy variable if firm $i$ has a general fiscal council installed ( $F C_{1}$ ), a permanent fiscal council $\left(F C_{1}\right)$, or a powerful fiscal council $\left(F C_{3}\right) ; C_{n}=$ variable that takes values for $F C_{n^{\prime}} A C, A C F C$, or ACOFC; $L E V=$ leverage of firm $i$ in period $t ; G R O=$ revenue growth of firm $i$ in period $t$; $A C O F C=$ dummy variable if firm $i$ has fiscal council or audit committee installed; $S=$ natural logarithm of total assets of firm $i$ in period $t$.

***,**, *: significant at $1 \%, 5 \%$, and $10 \%$, respectively.

Source: Prepared by the authors.

The models of columns 1, 2, 4, and 5 of Table 5 have, for the variables of interest, coefficients with no statistical significance, something which indicates that companies with a general fiscal council, an audit committee, and a permanent fiscal council do not raise market expectations in relation to net income and its contemporary variation to stock return.

Contrary to hypotheses 3 and 4 , the results for a powered fiscal council and the presence of both have negative and significant coefficients for the variables
$N I^{\star} \mathrm{FC}_{3}(-0.183, t=-0.68)$ and $N I^{\star} A C F C(-0.114, t=$ -1.99), showing that their presence does not improve the timeliness of accounting figures, i.e. the market anticipates net income information content. This result, as well as the result for relevance, contributes to academic and professional discussions about the overlapping of actions taken by the powered fiscal council.

Table 6 shows the results of regressions for the conditional conservatism model. 
Table 6 Results of the conditional conservatism model

\begin{tabular}{|c|c|c|c|c|c|c|}
\hline \multicolumn{7}{|c|}{$\begin{array}{c}\text { Model } 3 \\
N I_{i, t}=\beta_{0}+\beta_{1} \cdot D_{i, t}+\beta_{2} \cdot R_{i, t}+\beta_{3} \cdot R_{i, t}{ }^{*} D_{i, t}+\beta_{4} \cdot C_{n}+\beta_{5} \cdot D_{i, t}^{*} C_{n}+\beta_{6} \cdot R_{i, t}^{*} C_{n}+\beta_{7} \cdot R_{i, t}{ }^{*} D_{i, t}^{*} C_{n}+\sum_{1}^{n} \cdot \beta_{n} \cdot \text { Control }+\varepsilon_{i, t}\end{array}$} \\
\hline Column & 1 & 2 & 3 & 4 & 5 & 6 \\
\hline \multirow[t]{2}{*}{ Variables } & $\begin{array}{l}\text { General fiscal } \\
\text { council }\end{array}$ & $\begin{array}{l}\text { Audit } \\
\text { committee }\end{array}$ & Both & $\begin{array}{l}\text { Fiscal council or } \\
\text { audit committee }\end{array}$ & $\begin{array}{l}\text { Permanent fiscal } \\
\text { council }\end{array}$ & $\begin{array}{l}\text { Powered fiscal } \\
\text { council }\end{array}$ \\
\hline & $\mathrm{C}=\mathrm{FC}_{1}$ & $\mathrm{C}=\mathrm{AC}$ & $\mathrm{C}=\mathrm{ACFC}$ & $\mathrm{C}=\mathrm{ACOFC}$ & $\mathrm{C}=\mathrm{FC}_{2}$ & $\mathrm{C}=\mathrm{FC}_{3}$ \\
\hline \multirow{2}{*}{$R$} & 0.0811 & 0.0437 & 0.0448 & 0.0773 & 0.0375 & 0.0436 \\
\hline & $(0.46)$ & $(0.41)$ & $(0.42)$ & $(0.44)$ & $(0.35)$ & $(0.41)$ \\
\hline \multirow{2}{*}{$D$} & $-0.0835^{*}$ & -0.0772 & $-0.0797^{* *}$ & -0.0797 & $-0.0859 *$ & $-0.0827^{* *}$ \\
\hline & $(-1.91)$ & $(-1.59)$ & $(-2.03)$ & $(-1.18)$ & $(-1.96)$ & $(-2.41)$ \\
\hline \multirow{2}{*}{$R^{*} D$} & 0.114 & 0.271 & 0.271 & 0.118 & 0.253 & 0.273 \\
\hline & $(0.54)$ & $(1.40)$ & $(1.40)$ & $(0.56)$ & $(1.33)$ & $(1.39)$ \\
\hline \multirow{2}{*}{$C_{n}$} & -0.0117 & -0.00479 & 0.00613 & -0.0289 & -0.00398 & 0.0526 \\
\hline & $(-0.39)$ & $(-0.16)$ & $(0.19)$ & $(-0.89)$ & $(-0.12)$ & $(0.75)$ \\
\hline \multirow{2}{*}{$R^{*} C_{n}$} & -0.0976 & -0.0558 & -0.150 & -0.0897 & 0.153 & -3.589 \\
\hline & $(-0.53)$ & $(-0.24)$ & $(-0.48)$ & $(-0.49)$ & $(1.00)$ & $(-0.84)$ \\
\hline \multirow{2}{*}{$D^{*} C$} & 0.0716 & 0.0355 & 0.0191 & 0.0605 & 0.0734 & -0.0145 \\
\hline & $(1.45)$ & $(0.62)$ & $(0.35)$ & $(0.88)$ & $(1.41)$ & $(-0.19)$ \\
\hline \multirow{2}{*}{$R^{*} D^{*} C_{n}$} & 1.489 & 1.354 & 0.552 & 1.475 & $0.764^{* * *}$ & 2.304 \\
\hline & $(1.48)$ & $(1.63)$ & $(0.85)$ & $(1.50)$ & (3.05) & $(0.40)$ \\
\hline \multirow{2}{*}{$S$} & 0.0135 & 0.0147 & 0.0143 & 0.0153 & 0.0126 & 0.0140 \\
\hline & $(0.89)$ & $(0.92)$ & $(0.88)$ & $(1.05)$ & $(0.75)$ & $(0.83)$ \\
\hline \multirow{2}{*}{ GRO } & -0.0329 & -0.0136 & -0.0187 & -0.0300 & -0.0174 & -0.0236 \\
\hline & $(-0.62)$ & $(-0.25)$ & $(-0.36)$ & $(-0.55)$ & $(-0.33)$ & $(-0.45)$ \\
\hline \multirow{2}{*}{ LEV } & $-0.350^{* *}$ & $-0.351 *$ & $-0.352 *$ & $-0.351 * *$ & $-0.352^{* *}$ & $-0.352^{* *}$ \\
\hline & $(-1.97)$ & $(-1.97)$ & $(-1.97)$ & $(-2.00)$ & $(-1.97)$ & $(-1.98)$ \\
\hline \multirow{2}{*}{ Const. } & 0.0657 & 0.0384 & 0.0434 & 0.0542 & 0.0685 & 0.0507 \\
\hline & $(0.38)$ & $(0.21)$ & $(0.23)$ & $(0.33)$ & $(0.34)$ & $(0.25)$ \\
\hline $\mathrm{R}^{2}(\%)$ & 23.83 & 18.73 & 18.55 & 24.08 & 19.34 & 18.74 \\
\hline $\mathrm{F}$ & 5.46 & 3.10 & 3.07 & 6.98 & 10.28 & 2.01 \\
\hline Prob. F & 0.000 & 0.001 & 0.001 & 0.000 & 0.000 & 0.000 \\
\hline Clusters (n) & 209 & 209 & 209 & 209 & 209 & 209 \\
\hline Observations & 722 & 722 & 722 & 722 & 722 & 722 \\
\hline
\end{tabular}

Note: $N I_{i, t}$ is earnings per share of company $i$ in year $t$, scaled by share price at $t-1, R_{i, t}$ is return on share (the most liquid share class) of company $i$ in year $t$ adjusted by dividends and splits (four months after the end of the year) and scaled by share price at $t-1$ ( $C_{n}$ according to model 1). The first line shows the coefficients and the second line, the $t$ statistics. Standard error is robust and clustered by firm. The variables LPA and $R$ are scaled by price in $t-1$ (four months after the beginning of the year).

$A C F C=$ dummy variable if firm $i$ has both, fiscal council and audit committee, installed; $A C=$ dummy variable if firm $i$ has an audit committee installed; $C F_{n}=$ dummy variable if firm $i$ has a general fiscal council installed ( $F C_{1}$ ), a permanent fiscal council $\left(F C_{2}\right)$, or a powerful fiscal council $\left(F C_{3}\right) ; C_{n}=$ variable that takes values for $F C_{n^{\prime}} A C, A C F C$, or $A C O F C ; D=d u m m y$ variable considering 1 if the return is negative and 0 , otherwise; $L E V=$ leverage of firm $i$ in period $t$; GRO = revenue growth of firm $i$ in period $t$; $A C O F C=$ dummy variable if firm i has a fiscal council or an audit committee installed; $S=$ natural logarithm of total assets of firm $i$ in period $t$.

***,**, *: significant at $1 \%, 5 \%$, and $10 \%$, respectively.

Source: Prepared by the authors.

The results point out that only companies with a permanent fiscal council installed, according to column 5 of Table 6 , have an attribute of conditional conservatism, recognizing in advance their economic losses in net income, since the variable $R^{\star} D^{\star} C F_{2}$ has a positive and significant coefficient of $0.764(t=3.05)$.

Thus, there is evidence of a positive effect of the presence of a permanent fiscal council as a corporate governance mechanism that reinforces the good practices suggested by Almeida (2010), Bushman and Smith (2001), Lopes and Walker (2008), and Sloan (2001).

Table 7 summarizes the results found for the $\mathrm{H}_{1}$ hypothesis that the presence in Brazilian companies of an audit committee $\left(\mathrm{H}_{1}\right)$, a fiscal council $\left(\mathrm{H}_{2}\right)$, an audit committee $\left(\mathrm{H}_{3}\right)$, and both simultaneously $\left(\mathrm{H}_{4}\right)$ increases the quality of accounting information disclosed to the market. 
Table 7 Summary of results for the research hypotheses

\begin{tabular}{lcccc}
\hline Metrics & $\begin{array}{c}\text { Audit committee } \\
\left(\mathbf{H}_{\mathbf{1}}\right)\end{array}$ & $\begin{array}{c}\text { General fiscal council } \\
\left(\mathbf{H}_{2}\right)\end{array}$ & $\begin{array}{c}\text { Powered fiscal council } \\
\left(\mathbf{H}_{3}\right)\end{array}$ & $\begin{array}{c}\text { Both } \\
\left(\mathbf{H}_{\mathbf{4}}\right)\end{array}$ \\
\hline Relevance & Partially confirmed & Partially confirmed & Partially confirmed & Partially confirmed \\
\hline Timeliness & Not confirmed & Not confirmed & Not confirmed & Not confirmed \\
\hline Conservatism & Not confirmed & Partially confirmed & Not confirmed & Not confirmed \\
\hline
\end{tabular}

Source: Prepared by the authors.

\section{ROBUSTNESS ANALYSIS}

In order to reinforce the evidence found previously, we sought to change the variable of interest presence of an audit committee and a fiscal council by the independence degree of their members.

The fiscal council independence was analyzed in two ways: (i) members representing minority shareholders, elected at the general meeting (thus, independence from the controlling shareholders is expected), and (ii) independence with management, verifying present and past relations between the member and the company or economic group by means of item 12.8 of the company Reference Form.

As for independence of the audit committee, we could only use as a proxy member independence from management, because they were not directly elected by shareholders, making it impossible to analyze independence of the controlling shareholders. The number of observations in this analysis changed when compared to the previous one is due to the fact that some companies did not provide the full information, in the company Reference Form, of the members' curricula, both those from the fiscal council and the audit committee, something which resulted in a decreased number of observations.

The variable $D I N D_{1}$ is a dummy variable that takes value 1 when the company has at least one member elected by minority shareholders and 0 otherwise, the variable $I N D_{1}$ measures the percentage of members elected by minority shareholders, while the variable $D I N D_{2}$ takes value 1 when the company has at least one independent member and 0 otherwise, and the variable $I N D_{2}$ measures the percentage of independent members.

In the same structure, we analyze relevance, timeliness, and conditional conservatism. Table 8 displays results for the relevance model. 
Table 8 Results of the relevance model (independence)

\section{Model 1}

\begin{tabular}{|c|c|c|c|c|c|c|}
\hline Column & 1 & 2 & 3 & 4 & 5 & 6 \\
\hline \multirow{2}{*}{ Variables } & \multicolumn{4}{|c|}{ General fiscal council } & \multicolumn{2}{|c|}{ Audit committee } \\
\hline & DIND $_{1}$ & $\mathrm{IND}_{1}$ & DIND $_{2}$ & $\mathrm{IND}_{2}$ & DIND $_{2}$ & $\mathrm{IND}_{2}$ \\
\hline \multirow{2}{*}{$N I$} & $0.311^{* * *}$ & $0.271^{* * *}$ & $0.287^{* * *}$ & $0.240^{* * *}$ & $0.185^{* * *}$ & $0.192^{* * *}$ \\
\hline & $(5.52)$ & $(3.73)$ & $(5.20)$ & $(3.90)$ & $(3.76)$ & $(3.51)$ \\
\hline \multirow{2}{*}{$B V$} & $-0.0462^{* * *}$ & $-0.0383^{* * *}$ & $-0.0415^{* * *}$ & $-0.0409^{* * *}$ & $-0.0218^{* *}$ & $-0.0232 * * *$ \\
\hline & $(-5.64)$ & $(-4.91)$ & $(-5.54)$ & $(-4.08)$ & $(-3.45)$ & $(-2.70)$ \\
\hline \multirow{2}{*}{$I_{n}$} & 0.0320 & 0.0433 & $0.0528 *$ & 0.0178 & 0.0201 & 0.00630 \\
\hline & $(1.12)$ & $(0.74)$ & $(1.66)$ & $(0.46)$ & $(0.47)$ & $(0.09)$ \\
\hline \multirow{2}{*}{$N I^{*} I_{n}$} & $-0.145^{*}$ & $-0.134 *$ & -0.109 & -0.0379 & $0.535^{* * *}$ & $0.489 * * *$ \\
\hline & $(-1.66)$ & $(-1.86)$ & $(-1.20)$ & $(-0.46)$ & $(3.76)$ & $(3.36)$ \\
\hline \multirow{2}{*}{$B V^{*} I_{n}$} & $0.0367^{* * *}$ & $0.0577^{*}$ & $0.0266^{* *}$ & 0.0436 & 0.0348 & 0.0646 \\
\hline & $(3.56)$ & $(1.80)$ & $(2.32)$ & $(1.61)$ & $(0.66)$ & $(0.80)$ \\
\hline \multirow{2}{*}{$S$} & 0.00569 & 0.00853 & 0.00336 & 0.00732 & 0.00619 & 0.00629 \\
\hline & $(0.61)$ & $(0.92)$ & $(0.35)$ & $(0.76)$ & $(0.65)$ & $(0.65)$ \\
\hline \multirow{2}{*}{ GRO } & $0.106^{* *}$ & $0.101^{* *}$ & $0.111^{* *}$ & $0.107^{* *}$ & $0.0849^{*}$ & $0.0903^{*}$ \\
\hline & $(2.16)$ & $(2.11)$ & $(2.25)$ & $(2.17)$ & $(1.19)$ & $(1.87)$ \\
\hline \multirow{2}{*}{ LEV } & $-0.104 * * *$ & $-0.101^{* * *}$ & $-0.0994^{* * *}$ & $-0.108^{* * *}$ & $-0.0986^{* * *}$ & $-0.101^{* * *}$ \\
\hline & $(-2.89)$ & $(-2.79)$ & $(-2.80)$ & $(-2.83)$ & $(-1.77)$ & $(-2.91)$ \\
\hline \multirow{2}{*}{ Const. } & $0.968^{* * *}$ & $0.930^{* * *}$ & $0.984^{* * *}$ & $0.945^{* * *}$ & $0.962^{* * *}$ & $0.966^{* * *}$ \\
\hline & $(6.54)$ & $(6.25)$ & $(6.47)$ & $(6.13)$ & $(4.75)$ & $(6.26)$ \\
\hline $\mathrm{R}^{2}(\%)$ & 11.23 & 10.74 & 11.13 & 10.66 & 12.16 & 11.55 \\
\hline $\mathrm{F}$ & 6.53 & 6.89 & 6.64 & 5.50 & 9.21 & 8.49 \\
\hline Prob. F & 0.000 & 0.000 & 0.000 & 0.000 & 0.000 & 0.000 \\
\hline Clusters (n) & 210 & 210 & 204 & 204 & 208 & 208 \\
\hline Observations & 718 & 718 & 700 & 700 & 711 & 711 \\
\hline
\end{tabular}

Note: $P_{i, t}$ is the share price of company $i$ in year $t$ adjusted by dividends and splits (four months after the end of the year) and scaled by share price in $t-1, N I_{i, t}$ is earnings per share of company $i$ in year $t$ scaled by share price in $t-1, B V_{i, t}$ is equity per share of company $i$ in year $t$, scaled by share price in $t-1$. The first line shows the coefficients and the second line, the $t$ statistics. Standard error is robust and clustered by firm. The variables $P, L P A$, and PLA are scaled by price in $t-1$ (four months after the beginning of the year).

$D I N D_{n}=$ dummy variable if firm $i$ has at least one independent controller member (DIND $)_{1}$ or administration member $\left(D I N D_{2}\right)$ in the fiscal council or the audit committee; $L E V=$ leverage of firm $i$ in period $t ; l=$ variable that takes values for member independence; $I N D_{n}=$ percentage of independent controller members $\left(I N D_{1}\right)$ or administration members (IND $)$ in the fiscal council or the audit committee in firm $i ; G R O=$ revenue growth of firm $i$ in period $t ; S=$ natural logarithm of total assets of firm $i$ in period $t$.

***, **, *: significant at 1\%,5\%, and 10\%, respectively.

Source: Prepared by the authors. 
The results for relevance indicate that fiscal council independence positively impacts equity relevance in the two independence analyses and that of the audit committee only impacts net income relevance, reinforcing the previous results for relevance of analyzing the presence of these bodies.

Table 9 displays the results for the timeliness model.

Table 9 Results for the timeliness model (independence)

\begin{tabular}{|c|c|c|c|c|c|c|}
\hline \multicolumn{7}{|c|}{$\begin{array}{c}\text { Model } 2 \\
R=\beta+\beta N I+\beta \Delta N I+\beta I+\beta N I * I+\beta, \Delta N I * I+\Gamma^{n} \beta \text { Control }+\varepsilon\end{array}$} \\
\hline Column & 1 & 2 & 3 & 4 & 5 & 6 \\
\hline \multirow{2}{*}{ Variables } & \multicolumn{4}{|c|}{ General fiscal council } & \multicolumn{2}{|c|}{ Audit committee } \\
\hline & DIND $_{1}$ & $\mathrm{IND}_{1}$ & DIND $_{2}$ & $\mathrm{IND}_{2}$ & DIND $_{2}$ & $\mathrm{IND}_{2}$ \\
\hline \multirow{2}{*}{$\mathrm{NI}$} & $0.170^{* *}$ & $0.143^{*}$ & $0.172^{* *}$ & 0.132 & $0.136^{* * *}$ & $0.136^{* * *}$ \\
\hline & $(2.19)$ & $(1.89)$ & $(2.20)$ & $(1.65)$ & $(2.78)$ & $(2.79)$ \\
\hline \multirow{2}{*}{$\Delta \mathrm{N} I$} & 0.0149 & 0.00877 & 0.0148 & 0.0159 & 0.0133 & 0.0135 \\
\hline & $(0.67)$ & $(0.49)$ & $(0.65)$ & $(0.74)$ & $(0.81)$ & $(0.86)$ \\
\hline \multirow{2}{*}{$I_{n}$} & 0.0240 & 0.0427 & 0.00995 & 0.00985 & 0.0110 & 0.00468 \\
\hline & $(1.33)$ & $(1.56)$ & $(0.59)$ & $(0.56)$ & $(1.02)$ & $(0.40)$ \\
\hline \multirow{2}{*}{$N I^{*} I_{n}$} & -0.0575 & -0.0176 & -0.0510 & 0.0135 & -0.0687 & -0.0862 \\
\hline & $(-0.69)$ & $(-0.24)$ & $(-0.61)$ & $(0.18)$ & $(-1.10)$ & $(-1.41)$ \\
\hline \multirow{2}{*}{$\Delta \mathrm{N} I^{*} I_{n}$} & -0.00937 & 0.00491 & -0.00764 & -0.0111 & -0.00947 & -0.0129 \\
\hline & $(-0.39)$ & $(0.13)$ & $(-0.31)$ & $(-0.43)$ & $(-0.51)$ & $(-0.68)$ \\
\hline \multirow{2}{*}{$S$} & 0.00366 & 0.00498 & 0.00911 & 0.00983 & 0.00537 & 0.00592 \\
\hline & $(0.34)$ & $(0.46)$ & $(0.91)$ & $(0.97)$ & $(0.50)$ & $(0.54)$ \\
\hline \multirow{2}{*}{ GRO } & 0.0347 & 0.0328 & 0.0315 & 0.0301 & 0.0328 & 0.0330 \\
\hline & $(1.17)$ & $(1.10)$ & $(1.05)$ & $(0.98)$ & $(1.08)$ & $(1.09)$ \\
\hline \multirow{2}{*}{$L E V$} & 0.0633 & 0.0592 & 0.0739 & 0.0668 & 0.0573 & 0.0574 \\
\hline & $(0.94)$ & $(0.88)$ & $(1.11)$ & $(1.00)$ & $(0.89)$ & $(0.89)$ \\
\hline \multirow{2}{*}{ Const. } & -0.109 & -0.123 & -0.195 & -0.201 & -0.121 & -0.127 \\
\hline & $(-0.61)$ & $(-0.69)$ & $(-1.17)$ & $(-1.18)$ & $(-0.68)$ & $(-0.70)$ \\
\hline $\mathrm{R}^{2}(\%)$ & 5.23 & 5.04 & 7.12 & 6.92 & 4.93 & 4.93 \\
\hline $\mathrm{F}$ & 2.62 & 2.63 & 2.84 & 3.24 & 2.66 & 2.65 \\
\hline Prob. F & 0.052 & 0.050 & 0.071 & 0.002 & 0.049 & 0.049 \\
\hline Clusters (n) & 209 & 209 & 203 & 203 & 207 & 207 \\
\hline Observations & 688 & 688 & 673 & 673 & 681 & 681 \\
\hline
\end{tabular}

Note: $R_{i, t}$ is return on (the most liquid class) share of company $i$ in year $t$ adjusted by dividends and splits (four months after the end of the year) and scaled by share price in $t-1, N I_{i, t}$ is earnings per share of company $i$ in year $t$ and scaled by share price in $t-1$, and $\triangle B V_{i, t}$ are changes in net income per share of company $i$ in year $t$ and scaled by share price in $t-1$ ( $I_{n}$ according to model 1). The first line shows the coefficients and the second line, the $t$ statistics. Standard error is robust and clustered by firm. The variables $P, L P A$, and PLA are scaled by price in $t-1$ (four months after the beginning of the year).

$D I N D_{n}=$ dummy variable if firm $i$ has at least one independent controller member (DIND $D_{1}$ or administration member (DIND $\left.{ }_{2}\right)$ in the fiscal council or the audit committee; $L E V=$ leverage of firm $i$ in period $t ; I=$ variable that takes values for member independence; $I N D_{n}=$ percentage of independent controller members $\left(I N D_{1}\right)$ or administration members $\left(I N D_{2}\right)$ in the fiscal council or the audit committee in firm i; GRO = revenue growth of firm $i$ in period $t ; S=$ natural logarithm of total assets of firm $i$ in period $t$.

***,**, *: significant at 1\%,5\%, and $10 \%$, respectively.

Source: Prepared by the authors.

According to the results for timeliness, we cannot attest to the effect of member independence on earnings timeliness and its persistence, as well as when analyzing the presence of these bodies.

Table 10 displays the results for the conditional conservatism model. 
Table 10 Results for the conditional conservatism model (independence)

Model 3

\begin{tabular}{|c|c|c|c|c|c|c|}
\hline Column & 1 & 2 & 3 & 4 & 5 & 6 \\
\hline \multirow{2}{*}{ Variables } & \multicolumn{4}{|c|}{ General fiscal council } & \multicolumn{2}{|c|}{ Audit Committee } \\
\hline & DIND $_{1}$ & $\mathrm{IND}_{1}$ & DIND $_{2}$ & $\mathrm{IND}_{2}$ & DIND $_{2}$ & $\mathrm{IND}_{2}$ \\
\hline \multirow{2}{*}{$D$} & $-0.0758^{* *}$ & -0.0471 & $-0.0814^{*}$ & -0.0535 & $-0.0768^{*}$ & $-0.0739 *$ \\
\hline & $(-2.19)$ & $(-1.29)$ & $(-1.91)$ & $(-1.07)$ & $(-1.68)$ & $(-1.72)$ \\
\hline \multirow{2}{*}{$R^{*} D$} & 0.116 & 0.0955 & 0.119 & 0.103 & 0.271 & 0.271 \\
\hline & $(0.55)$ & $(0.46)$ & $(0.56)$ & $(0.48)$ & $(1.40)$ & $(1.39)$ \\
\hline \multirow[b]{2}{*}{$I_{n}$} & -0.0160 & -0.00225 & -0.0129 & 0.0163 & -0.0248 & -0.0329 \\
\hline & $(-0.52)$ & $(-0.07)$ & $(-0.42)$ & $(0.66)$ & $(-0.87)$ & $(-0.90)$ \\
\hline \multirow{2}{*}{$R^{*} I_{n}$} & -0.0960 & -0.158 & -0.000721 & 0.00580 & 0.0126 & -0.146 \\
\hline & $(-0.52)$ & $(-0.41)$ & $(-0.00)$ & $(0.03)$ & $(0.05)$ & $(-0.39)$ \\
\hline \multirow{2}{*}{$D^{*} I_{n}$} & 0.0614 & 0.0812 & $0.0842 *$ & 0.0549 & 0.0328 & 0.0172 \\
\hline & $(1.49)$ & $(0.95)$ & $(1.70)$ & $(0.89)$ & $(0.58)$ & $(0.23)$ \\
\hline \multirow{2}{*}{$R^{*} D^{*} I_{n}$} & 1.486 & $4.496^{* * *}$ & 1.599 & $1.962 *$ & 1.273 & 1.571 \\
\hline & $(1.47)$ & $(4.04)$ & $(1.43)$ & $(1.71)$ & $(1.43)$ & $(1.34)$ \\
\hline \multirow{2}{*}{$S$} & 0.0143 & 0.0164 & 0.0127 & 0.0130 & 0.0164 & 0.0171 \\
\hline & $(0.93)$ & $(1.10)$ & $(0.81)$ & $(0.85)$ & $(1.02)$ & $(1.05)$ \\
\hline \multirow{2}{*}{$G R O$} & -0.0337 & -0.0374 & -0.0312 & -0.0291 & -0.0162 & -0.0160 \\
\hline & $(-0.63)$ & $(-0.68)$ & $(-0.57)$ & $(-0.53)$ & $(-0.31)$ & $(-0.30)$ \\
\hline \multirow{2}{*}{ LEV } & $-0.350^{*}$ & $-0.333^{*}$ & $-0.345^{*}$ & $-0.344^{*}$ & $-0.352^{*}$ & $-0.353^{*}$ \\
\hline & $(-1.97)$ & $(-1.92)$ & $(-1.95)$ & $(-1.95)$ & $(-1.97)$ & $(-1.97)$ \\
\hline \multirow{2}{*}{ Const. } & 0.0555 & 0.00542 & 0.0722 & 0.0495 & 0.0180 & 0.00867 \\
\hline & $(0.32)$ & $(0.03)$ & $(0.41)$ & $(0.28)$ & $(0.10)$ & $(0.05)$ \\
\hline $\mathrm{R}^{2}(\%)$ & 23.86 & 33.83 & 24.72 & 26.78 & 18.76 & $18.81 \%$ \\
\hline $\mathrm{F}$ & 5.10 & 7.11 & 5.28 & 6.57 & 2.94 & 2.71 \\
\hline Prob. F & 0.000 & 0.000 & 0.000 & 0.000 & 0.002 & 0.004 \\
\hline Clusters (n) & 209 & 209 & 203 & 203 & 207 & 207 \\
\hline Observations & 722 & 722 & 704 & 704 & 715 & 715 \\
\hline
\end{tabular}

Note: $N I_{i, t}$ is earnings per share of company $i$ in year $t$, scaled by share price at $t-1$ and $R_{i, t}$ is return on share (the most liquid share class) of company $i$ in year $t$ adjusted by dividends and splits (four months after the end of the year) and scaled by share price at $t-1\left(C_{n}\right.$ according to model 1$)$. The first line shows the coefficients and the second line, the $t$ statistics. Standard error is robust and clustered by firm. The variables LPA and $R$ are scaled by price in $t-1$ (four months after the beginning of the year). $D=$ dummy variable considering 1 if the return is negative and 0 , otherwise; DIND $=$ dummy variable if firm i has at least one independent controller member (DIND, ) or administration member $\left(D I N D_{2}\right)$ in the fiscal council or the audit committee; $L E V$ = leverage of firm $i$ in period $t ; l=$ variable that takes values for member independence; $I N D_{n}=$ percentage of independent controller members (IND1) or administration members $\left(I N D_{2}\right)$ in the fiscal council or the audit committee in firm $i$; $G R O=$ revenue growth of firm $i$ in period $t$; $S=$ natural logarithm of total assets of firm $i$ in period $t$.

***, **, *: significant at 1\%,5\%, and 10\%, respectively.

Source: Prepared by the authors.

According to the results presented in Table 10, the percentage of independent members in the fiscal council, either elected by minority shareholders or independent members, has an impact on reported profit conservatism. However, the results do not point out an association between member independence in the audit committee and the practice of conditional conservatism.

Therefore, we notice that member independence in the fiscal council managed to change the impact of the presence of this body on conditional conservatism. The results for audit committee independence reinforce the evidence found for its presence. 


\section{FINAL REMARKS}

This study evaluated the effects of the presence of the audit committee and the fiscal council and their various arrangements on earnings quality of Brazilian public companies listed on the BM\&FBOVESPA from 2010 to 2013. The metrics to assess earnings quality were: relevance, timeliness, and conditional conservatism. The motivation for conducting this research focused on the perspective of these bodies functioning as a mechanism of corporate governance, especially in the functions of supervision and inspection of the financial reporting process.

In general, the results indicated that the bodies under study have an effect on the quality of accounting figures. However, a conclusion must be drawn according to each research hypothesis, body configurations, and accounting information properties.

The results for the audit committee and the general fiscal council indicated impacts only on the relevance of accounting information: impact on net income, for the audit committee, and on equity, for the general fiscal council, partially confirming the hypotheses $\mathrm{H}_{1}$ e $\mathrm{H}_{2}$.

In parallel, the results pointed out a high impact of the audit committee on net income relevance (high coefficient and significance). This evidence may be explained by the specificity of the functions of the committee in the financial reporting process, coming from internal controls to internal and external audit inspection, while the fiscal council has broader functions/powers, but it has the possibility of accessing information from the auditors and the audit committee when inspecting audited financial statements and the executives' acts.

The fact that the general fiscal council has had a positive and significant effect only on equity relevance and a negative effect on earnings relevance (although not significant) may indicate a greater concern of the fiscal council in protecting the shareholders' equity, while the concern of the audit committee may be greater in ensuring more reliable data on managers' performance (contained in the income statements).

It is worth highlighting that this assumption is that the concerns might be differently evidenced in each body (greater focus on one or another goal, based on its functions and hierarchies). Objectively, if net income is relevant to an investor, then the audit committee acts by improving financial reporting quality, since its members, directly or indirectly, were nominated by controlling and minority shareholders, while the fiscal council members are predominantly elected by controlling shareholders or a group of shareholders, detaching small investors and shareholders, and giving greater emphasis to equity, as the fiscal council members are elected and directly report to shareholders at meetings.

It was expected that the presence of both in the same organization might improve the financial reporting process. The evidence showed an increase in net income relevance, but the results for timeliness pointed out negative effects. Thus, in this scenario, net income is relevant to the market, but not in a timely way, something which exposes a restriction to the relevance found. Also, the existence of one or the other body, in contrast to none, only impacted equity relevance.

The results obtained in this research pointed out higher relevance of net income and equity in companies with a permanent fiscal council installed, as well as higher conditional conservatism, something which reflects the financial reporting function as a contractual mechanism. These results are mutually related, since early recognition of economic losses in earnings (conditional conservatism) tends to make this information more relevant to the market. Such evidence has indicated that fiscal councils permanently installed may be considered as more efficient corporate governance mechanisms than when installed only at shareholders' request.

We also found a positive impact of a powered fiscal council only on equity relevance. This evidence suggests that poor association of a powered fiscal council with earnings quality metrics may be a reflection of the various functions of this body, and this can affect its focus. Such a result may be useful for regulators, market players, and shareholders when discussing better corporate governance models.

Finally, corporate governance is a complex and dynamic system that involves the interaction of a set of components. Thus, evaluating the impact of one or the other component on earnings quality may be a limiting factor, something which gives room for further research in order to deepen and improve a major theme for accounting practitioners, and above all for accounting information users, seeking to relate other governance mechanisms, as well as other accounting information properties 


\section{REFERENCES}

Ahmed, K., \& Henry, D. (2012). Accounting conservatism and voluntary corporate governance mechanisms by Australian firms. Accounting \& Finance, 52, 631-662.

Almeida, J. E. F. (2010). Qualidade da informação contábil em ambientes competitivos (Ph.D. Thesis). Faculdade de Economia, Administração e Contabilidade, Universidade Federal de São Paulo, São Paulo.

Barth, M. E., Landsman, W. R., \& Lang, M. H. (2008). International accounting standards and accounting quality. Journal of Accounting Research, 46(3), 467-498.

Basu, S. (1997). The conservatism principle and the asymmetric timeliness of earnings. Journal of Accounting and Economics, 24, 3-37.

Baxter, P., \& Cotter, J. (2009). Audit committee and earnings quality. Accounting and Finance, 49(2), 267-290.

Birkett, B. S. (1986). The recent history of corporate audit committees. The Accounting Historians Journal, 13(2), 109124.

Brasil (1976). Lei n. 6.404, de 15 de dezembro de 1976. Dispõe sobre as sociedades por ações. Brasília, DF: Diário Oficial da União. Retrieved from http://www.planalto.gov.br.

Bushman, R. M., \& Smith A. J. (2001). Financial accounting information and corporate governance. Journal of Accounting and Economics, 32, 237-333.

Bushman, R. M., Chen, Q., Engel, E., \& Smith, A. J. (2004). Financial accounting information, organizational complexity and corporate governance systems. Journal of Accounting and Economics, 37, 167-201.

Calazans, E. (2003, August 27). Conselho fiscal x comitê de auditoria. Gazeta Mercantil. Legal e Jurisprudência. Retrieved from http://www.citadini.com.br/auditoria/gm030827.htm.

Carvalhal-da-Silva, A. L., \& Leal, R. P. C. (2005). Corporate governance index: firm valuation and performance in Brazil. Revista Brasileira de Finanças, 3(1), 1-18.

Chtourou, S. M., Bédard, J., \& Courteu, L. (2001). Corporate governance and earnings management [Working Paper]. Social Science Research Network. Retrieved from http://papers. ssrn.com/sol3/papers.cfm?abstract_id=275053.

Cunha, P. R., Hillesheim, T., Faveri, D. B., \& Rodrigues, M. M., Jr. (2014). Características do comitê de auditoria e o gerenciamento de resultados: um estudo nas empresas listadas na BM\&FBOVESPA. Revista de Contabilidade e Organizações, $8(22), 15-25$

Dechow, P. M., Ge, W., \& Schrand, C. (2010). Understanding. earnings quality: a review of the proxies, their determinants and their consequences [Working Paper]. Social Science Research Network. Retrieved from http://papers.ssrn.com/ sol3/papers.cfm?abstract_id=1485858.

Dechow, P. M., Sloan, R. G., \& Sweeney, A. P. (1996). Causes and consequences of earnings manipulation: an analysis of firms subject to enforcement actions by the SEC. Contemporary Accounting Research, 13(1), 1-36.

Felo, A. J., Krishnamurthy, S., \& Solieri, A. S. (2003). Audit committee characteristics and the perceived quality of financial reporting: an empirical analysis [Working Paper].
Social Science Research Network. Retrieved from http://papers. . ssrn.com/sol3/papers.cfm?abstract_id=401240.

Filipin, R. (2012). Relação do comitê de auditoria com a qualidade da informação contábil: evidências nas empresas listadas na

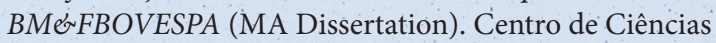
Sociais Aplicadas, Universidade Regional de Blumenau, Blumenau.

Furuta F., \& Santos, A. D. (2010): Comitê de auditoria versus conselho fiscal adaptado: a visão dos analistas de mercado e dos executivos das empresas que possuem ADRs. Revista Contabilidade \&े Finanças, 21(53), 1-23.

Giroud, X., \& Mueller, H. M. (2010). Corporate governance matter in competitive industries? Journal of Financial Economics, 95, 312-331.

He, L., Labelle, R., Piot, C., \& Thornton, D. B. (2009). Board monitoring, audit committee effectiveness and financial reporting quality: review and synthesis of empirical evidence. Journal of Forensic \& Investigative Accounting, 1(2), 1-41.

Instituto Brasileiro de Governança Corporativa. (2009). Guia de orientação para melhores práticas de comitês de auditoria. São Paulo, SP: IBCG.

Instituto Brasileiro de Governança Corporativa. (2010). Código das melhores práticas de governança corporativa. São Paulo, SP: IBCG.

Jensen M. C., \& Meckling, W. (1976). Theory of the firm: managerial behavior, agency cost, and ownership structure. Journal of Financial Economics, 3(4), 305-360.

Klein, A. (2002). Audit committee, board of director characteristics, and earnings management. Journal of Accounting Economics, 33(3), 374-400.

Lopes, A. B. (2009). The relation between firm-specific corporate governance, cross-listing and the informativeness of accounting. numbers in Brazil (Ph.D. Thesis). Manchester Business School, University of Manchester, Manchester.

Lopes, A. B., \& Walker, M. (2008). Firm-level incentives and the informativeness of accounting reports: an experiment in Brazil [Working Paper]. Social Science Research Network. Retrieved from http://ssrn.com/abstract=1095781 or http://. dx.doi.org/10.2139/ssrn.1095781.

PricewaterhouseCoopers. (2007). Comitês de auditoria no Brasil: melhores práticas de governança corporativa - o desafio continua (2a. ed.), Brasil: PwC. Retrieved from https://w.ww. pwc.com.br/pt/publicacoes/assets/melhores-praticas-07.pdf.

Santos, A. G. D. (2009). Comitê de auditoria: uma análise baseada na divulgação das informações de empresas brasileiras (Ph.D. Thesis). Faculdade de Economia, Administração e Contabilidade, Universidade de São Paulo, São Paulo.

Sloan, R. (2001). Financial accounting and corporate governance: a discussion. Journal of Accounting and Economics, 32, 335347.

Tinoco, J. E. P., Escuder, S. A. L., \& Yoshitake, M. (2011). O conselho fiscal e a governança corporativa: transparência e gestão de conflitos. Revista Contemporânea de Contabilidade, $8(16), 175-202$. 
Trapp, A. C. G. (2009). A relação do conselho fiscal como componente de controle no gerenciamento de resultados contábeis (Ph.D. Thesis). Faculdade de Economia,

- Administração e Contabilidade, Universidade Federal de São Paulo, São Paulo.

U.S. Government. Public Law 107-204, 30 Jul. 2002. SarbanesOxley Act. An act to protect investors by improving the accuracy and reliability of corporate disclosures made pursuant to the securities laws, and for other purposes. U.S: Government Publishing Office, Washington, DC, 30 Jul. 2002.
Retrieved from https://www.sec.gov/about/laws/soa2002.pdf. Vafeas, N. (2000). Board structure and the informativeness of earnings. Journal of Accounting and Public Policy, 19(2), 139160.

Wild, J. J. (1996). The audit committee and earnings quality. Journal of Accounting, Auditing and Finance, 11(2), 247-276.

Xie, B., Davidson, W. N., \& Dadalt, P. J. (2003). Earnings management and corporate governance: the role of the board and the audit committee. Journal of Corporate Finance, 9, 295-316.

\section{Correspondence address:}

Vitor Gomes Baioco

Universidade Federal do Espírito Santo, Centro de Ciências Jurídicas e Econômicas, Departamento de Ciências Contábeis Av. Fernando Ferrari, 514, ED-VI, sala 618 - CEP: 29075-910

Goiabeiras - Vitória - ES - Brasil

Email: vitorbaioco@gmail.com 